\title{
Architectural visions
}

\section{Reima Pietilä's nature architecture and his 'shamanistic' design method}

\begin{abstract}
$\mathrm{n}$ this article I examine the architecture and architectural thinking of Finnish Academician ${ }^{1}$ Reima Pietilä (1923-93) in relation to his design methodology. Pietilä was an architect with an original, creative, artistic personality, who set out early in his career to develop the form language, and theory of modern architecture, moving it towards an organic expressionism. Finnish nature mysticism was a source of inspiration for him, and 'nature architecture' one of his key concepts.
\end{abstract}

\section{Introduction}

The most far-reaching legacy of Pietiläs life's work is his formulation - in words, images and buildings - of an architectural theory based on a relationship with nature as well as the cultural objectification' of nature architecture. He formulated a contemporary philosophy of architecture, in which the classical theory of mimesis acquires a new interpretation based on both a cultural conception of nature and as a romantic imitation of nature that emphasises local identity. What was particularly distinctive about Pietilä was his personal and multidimensional design method, in which he utilised intuition as well as the verbal and visual 'power of imagination'.

1 Reima Pietilä was an Academician of Art, which is an honorary title awarded by the President of Finland.

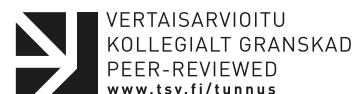

PEER-REVIEWED
www.tsv.fi/tunnus

Pietilä was widely read and had internalised European philosophy within his thinking. He also actively followed international developments in architecture, though he still felt that the link between Finnish nature and culture was most important to him and his approach remained - as he himself characterised it - within the tradition of 'Finno-Ugric shamanism'. Pietiläs conception of reality was metaphysical. He had the perceptiveness and sensitive intuition of a 'seer', which enabled him to move around within his imagination, unhindered by time and space, so as to 'see' inside phenomena to the core of their essence. ${ }^{2}$ Pietiläs architecture cannot

2 Reima Pietilä himself used the Finnish term selvänäentä (clairvoyance) when speaking about his working method (see Norri 1985: 26-7). Also, when I interviewed Pietilä in 1987 , he repeatedly used expressions that referred to clairvoyance - the intuitive ability to see or become aware of phenomena through extrasensory perception, with a deepened consciousness - as, for instance, when he tells of his 'shamanistic excursions' to prehistoric times, as well as his ability to 'see' things and their core, so that he can draw and tell about what he sees (Broner 2019: $26-37,48-9,62-3,80-1,94-5$ et passim). 
be understood without taking into account his intuitive approach, visionary thinking and artistic personality.

The present article is mainly based on my book Visions of Architecture: Reima Pietilä and the Meanings of Form (Broner 2019). ${ }^{3}$ The key sources - as also in the book - are Pietiläs own theoretical-philosophical writings together with interviews in which he discusses his architectural thinking and design processes. It should nevertheless be kept in mind that during his lifetime, Pietilä was very much misunderstood, and both his architectural works and writings were often dismissed or misinterpreted from a basis of not knowing or understanding their philosophical and visionary premises. When writing about the critique Pietilä received in Finland, Malcolm Quantrill refers to the well-known saying Nemo Propheta in Patria, which the architect Alvar Aalto also had rather mischievously chosen as the name of his own boat. ${ }^{4}$ Compared to Aalto, however, for

3 Broner 2019. The book, with texts in both Finnish and English, includes an 'historic' interview with Reima Pietilä from 1987 now published for the first time in full - and my essay about Pietiläs life's work and its significance, as well as an epilogue by MarjaRiitta Norri covering the controversial debate in the late 1960s about the Pietiläs' Dipoli building in Espoo. The present article includes sections from the book.

4 See Quantrill 2007: 125ff. According to Malcolm Quantrill: 'Pietilä was not at all worldly in the conventional sense. Rather, he was almost entirely other-worldly, possessing very little in common with our regularised academic and intellectual worlds. In cartographic terms, therefore, we have to accept that Pietiläs ideas were characteristically "off the map". Perhaps it was because Pietilä held such tough, other-worldly convictions that he was able to survive harsh winters of Finnish critical abuse' (ibid. p. 128, my emphasis). most of Pietiläs career there were far fewer people who understood his point of view. ${ }^{5}$ From the late 1960s until the early 1990s, a kind of trenchant atmosphere pervaded the architectural profession in Finland, and particularly among the small circle of architects who also actively wrote about architecture. They criticised and disapproved of Pietiläs experimental expressionist and neo-regionalist works. ${ }^{6}$ In my view, the sometimes even sarcastic critique was often based on a conscious reluctance to understand a dissenting colleague, because their motives were influenced by an emotionally-tuned 'trench warfare' regarding the question of 'what is architecture?' Against this backdrop, in my own study of Pietilä I have wanted primarily to listen to the architect's own voice, and as such I have disregarded the critics' content-wise idiosyncratic statements. On the other hand, even positive analyses and interpretations of Pietiläs architecture have often focused

5 Among Pietiläs colleagues who appreciated his work was the architect, Professor Aarno Ruusuvuori. He served as a judge in several architectural competitions won by Pietiläs office. Ruusuvuori's attitude is noteworthy in that his own works had a notable minimalist expression, that is, the opposite of Pietiläs architecture. In a class of their own were the architecture students, both in Finland and abroad, who were interested in Pietiläs work and his contextual architectural theory. Even among students, however, there was something of a 'love-or-hate' attitude towards Pietiläs architecture, just as in professional circles.

6 See e.g. Passinmäki 2003: 84-5. In his article, Pekka Passinmäki presents a few examples of critiques of Pietiläs writings and architecture. See also the case described by Kati Blom, in which a female architecture student severely criticises Raili and Reima Pietiläs proposal 'Mica Moraine', which won the architectural competition for the Official Residence of the President of Finland in 1983 (Blom 2007: 24-5). 
on certain, more or less, limited aspects of his work while ignoring the metaphysical dimension of his architecture.

\section{The cultural context}

Reima Pietilä was born in Turku, Finland, on 25 August 1923. His parents had returned a few years earlier from the United States, where both had emigrated separately, and where they had first met and also later married. His parents' years in the USA had left a cultural imprint on the family; for instance, English was also spoken at home as a second language after Finnish. Cultural differences and different linguistic idiosyncrasies fascinated the young boy already early on and also marked his later life.

When still a teenager, Pietilä attended lectures in Finno-Ugric languages as well as ethnology and philosophy at the University of Turku, and indeed he had originally planned a career in philosophy. His experiences in Karelia during the Second World War, however, changed his mind. In particular, the spatial experience of the forests of Dvina and the experience of surviving there at the mercy of nature left a deep impression (Pietilä s.d.: 4-5). Also, his mother's encouragement and belief that her son would become an architect, as foretold to her by a clairvoyant while she was living in the USA, ${ }^{7}$ apparently reinforced

7 Reima Pietilä had been told by his mother, Ida Maria Pietilä (née Lehtinen), that when aged 18-19, while working in the United States as a domestic servant for a 'clairvoyant' American Jewish lady, one day the lady told the young Ida that she had 'received' an important message: Ida would soon marry and have two children, a daughter who would become an artist and a son who would become an architect. After Ida married Frans Vihtori Pietilä, their first child, Tuulikki Pietilä, was born in Seattle, USA, in 1917 and later would become a respected his calling to the architecture profession.

After the war, Pietilä studied architecture at Helsinki University of Technology, graduating in 1953. His years at the University of Turku, however, had instilled a life-long interest in philosophy, linguistics and ethnology. He had extensive knowledge of Western philosophy and was familiar with contemporary thinking in philosophy and the social sciences. He had a special affinity for Ludwig Wittgenstein, and his architectural thinking had various points in common with the philosopher; for example, a profound interest in language and linguistic meanings. In particular, Pietilä felt strongly about the Finno-Ugrian languages and culture, and he always kept an etymological dictionary of the Finnish language close at hand.

Pietilä's architectural thinking was inspired by the roots and characteristics of Finnish culture, including linguistic phenomena and various nature-based experiences and atmospheres. He had a sensitive feel for line and form, but was also interested in theory, about which he wrote prolifically. He participated actively in debates on architecture both at home and abroad and often took the initiative in starting a debate. He also critiqued the prevailing atmosphere in Finnish architecture. He felt annoyed by the one-dimensional over-specialisation of - in Pietiläs own characterisation - the narrow-minded archi-technocrat' (cf. Lehtimäki 2007: 82) and by the strict adherence to certain 'academic' conventions followed by the majority of architects. According to him, a particular misfortune of architecture was the vision that only one style framework could

graphic artist. Reima Pietilä was born in 1923 in Turku, to where Ida and Frans Pietilä had returned in around 1920 (Quantrill 1985: 26). 
be correct' (Pietilä 1985a: 18). In addition to their artistic goals, ${ }^{8}$ all Pietiläs projects comprised a theoretically-conscious content. In terms of architectural practice, he worked in partnership with his wife, architect Raili Pietilä (b. 1925, née Paatelainen) in their joint office, founded in 1960.

'Nature-architecture' is a neologism coined by Pietilä in the 1980 s. He referred to it in regard to his own work, but apparently also in reference to Alvar Aalto's architecture, or at least those works that followed organic forms. He admired Aalto's approach and found himself moving down a path mapped out by the maestro, albeit in his own way and perhaps with, in his estimation, a more 'artistic approach' (Quantrill 2007: 127). However, following Aalto's death in 1976, when Pietilä came to be regarded as his architectural heir and became his successor in receiving in 1982 the honorary title of Academician of Art, he stated his own position unequivocally: 'I will not become the new Aalto. All my work has been a conscious assertion of the non-academic' (Nurmela 1982).

\section{Architecture's theoretical-philosophical grounds}

Pietilä began to develop his own morphological theory of architecture in the 1950 s and published his first significant article on the topic in the French-language international architecture journal Le Carré Bleu in 1958. This new type of publication had been founded in Helsinki in the previous year under the direction of architect Aulis Blomstedt as an international forum for discussion of architectural theory - and Pietilä himself was one of its

8 Pietilä: 'The artistic goal must be integrated into the working method from the outset.' See 'Reima Pietilän haastattelu' 1979: 16. founders as well as a member of its editorial board. The publication of the new theory journal was linked to discussions taking place during the disbandment of CIAM (Congrès Internationaux d'Architecture Moderne). Pietilä was actively involved in them, including those instigated by the architect group Team 10 alongside CIAM, up until its final congress in 1958, and afterwards in the group's own gatherings (Niskanen 2008: 24ff.). The founding of $L e$ Carré Bleu also marked a protest against the anti-theoretical attitude then prevailing among architects in Finland. Aalto himself, who was then the president of the Finnish Association of Architects (SAFA) at the time, was a 'reluctant writer' (Schildt 1972: 7-8). His famous dictum 'The Lord made paper so that architecture can be drawn on it. Everything else - at least for me - is a misuse of paper' (Aalto 1958: 27) had a wide influence on the contemporary architectural atmosphere in Finland.

In his article in Le Carré Bleu (1/1958) titled 'Thème: la morphologie de l'expression plastique, Pietilä still followed Blomstedt's doctrines in emphasising, for instance, the need to re-evaluate the morphological means of architecture in view of new developments in mathematics. For Pietilä, however, his article also marked his farewell to 'numerical aesthetics' (Norri 1985: 9-10). His future views on architecture were foreshadowed by his interest in reconciling theories of morphology and topology into a spatial art. In the article he also posed rhetorical questions: 'Isn't architectural composition still a largely unknown world and aren't there important means that have not yet been taken into use?' (Pietilä 1958: 5). Pietilä maintained that although 'new forms seem to flow from mysterious sources of spatial infinity, an exploration by intuition alone always remains fragmentary. He believed that 
the 'systematic study' of architecture could introduce new insights into the 'universe of visual form' (ibid.). While Pietiläs statement expressed his own choice of direction, it can also be seen as anticipating a change in the education of architects at a time when universities did not usually conduct any research in architecture other than research by design, ${ }^{9}$ and Finnish architects received artistic and technical design training mainly in accordance with the Bauhaus tradition.

Pietilä received his first significant building commission after winning the architectural competition for the Finnish pavilion at the Brussels World's Fair in 1956. The pavilion was completed in 1958 , and consequently raised international awareness of the young architect. Through the building's sculptural wooden structure, Pietilä aimed to continue the long tradition of Finnish wooden architecture. At the same time, its rectangular spatial modules and abstract composition were applications of a mathematical theory of morphology

9 It was only during subsequent decades that architectural research began to increase and doctoral programmes were established in universities more generally. In his inaugural lecture at the University of Oulu in 1973, Pietilä spoke strongly in favour of research: 'Architecture is not equipped with sufficient knowledge-based tools to cope with the tasks that it has accumulated. The straight-forward methods of technoculture and a supplementary strategy, which resemble arithmetic, do not favour the exploitation of the potential possessed by architecture. ... [A]rchitecture can no longer survive - preserve its meaning - on the basis of aggregate data alone. Research into the very foundations of [architectural] knowledge must also be taken into account. In this way, it is obviously necessary to recognise that architecture involves a number of epistemological issues that are specific to this field' (Pietilä 1973: 21).

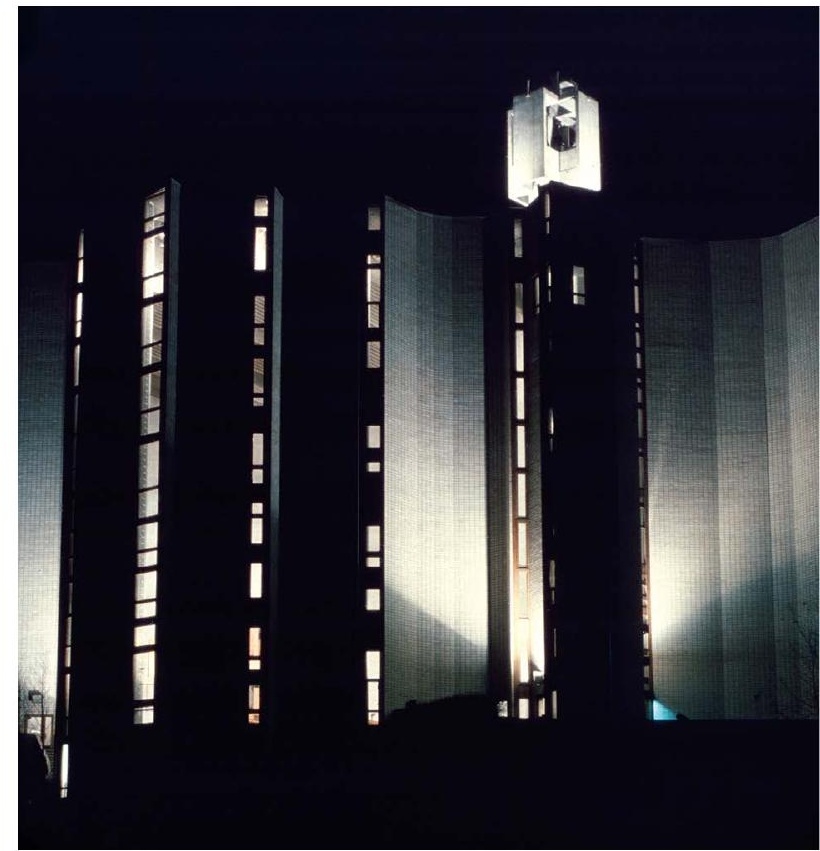

Kaleva Church (1959-66), exterior view (s.d.). Author's archives (Pietilä office donation).

developed in the spirit of the Le Carré Bleu group.

The Brussels pavilion marked the beginning of a series of projects by Pietilä linked to his studies in the theory of form. Almost all of the key building commissions Pietilä's office acquired over the next three decades came through winning architectural competitions. The main characteristic of these works was an inspired dialogue between theory, research and practice, incorporating both texts and images.

Following the Brussels pavilion, Pietilä's next successful competition entry was for the Kaleva Church in Tampere in 1959. This was the first time where ideas emerged that Pietilä would later refer to as 'nature architecture'. He explained how in the summer during the initial stage of developing ideas for this project he had gone canoeing and had observed the free movement of waves on the sea and the formation of clouds in the sky. A number of other natural and symbolic themes also influenced 


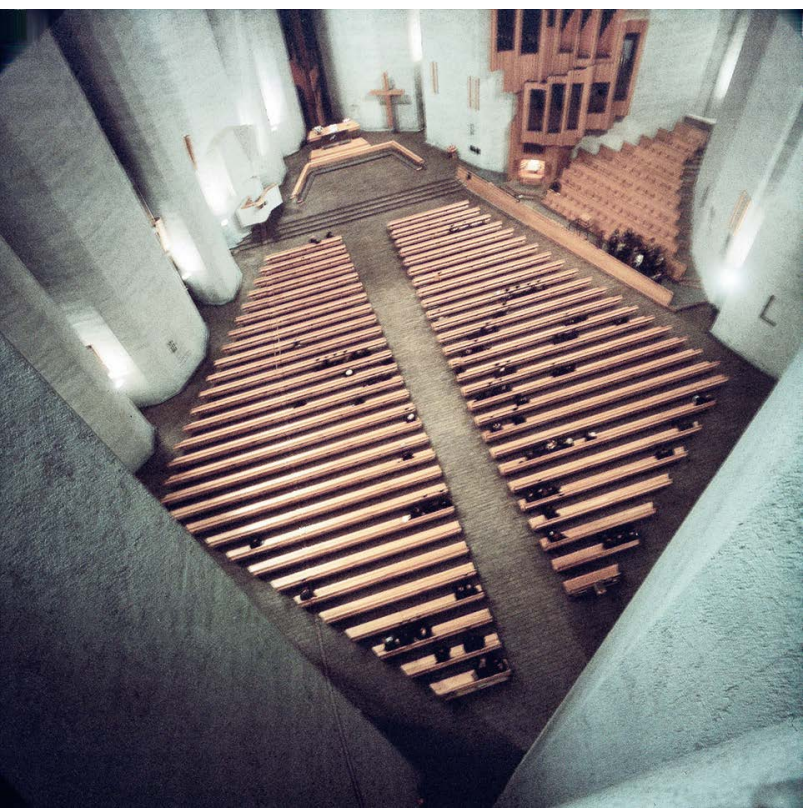

Kaleva Church (1959-66), interior view (s.d.). Author's archives (Pietilä office donation).

the church's architecture; for instance, the spatial experience of Finnish pine forests, the infinite space of Baroque churches, and the Christian metaphor of the fish as seen in the floor plan of the church (Pietilä s.d.: 3-4). The resulting architecture, the immense single-volume nave and concaveconvex geometric composition, are experientially both a monumental sanctuary and an open, sculptural space. Pietiläs aim in the design of the church interior had been architecture as spatial sculpturality, and he later stated that he had been aware of the Italian futurist artist Umberto Boccioni's concept of 'sculptural space.' 10 The rays of

10 See Pietilä 1974: 97. In the article, Pietilä also states that the Kaleva Church became a 'tribute to Boccioni'. The artist Umberto Boccioni (1882-1916) was a leading figure in Italian Futurism, and in 1912 he published the 'Manifesto tecnico della scultura futurista' (Manifesto of Futurist sculpture), light falling through the nave's tall vertical ribbon windows create a powerful spiritual atmosphere in the interior.

Upon its completion in 1966, the Kaleva Church demonstrated that Pietiläs plastic vision of architecture had matured into an autonomous expression. Its monumental form language was a synthesis of resources from organic, expressionist and classical architecture. The simultaneous use of two or more different stylistic ingredients and superimposed symbolic themes, leading to an ambiguity in the meaning of form, is also characteristic of Pietiläs later architecture. In the complexity of the church's metaphorical form language, one can see Christian and nature-inspired symbolism but also cultural markers that anticipate postmodernism - despite the fact that throughout his entire career Pietilä declared himself to be continuing modernism and was not interested in postmodernist stylistic experiments.

An architectural competition was held in 1961 for a new Student Union building, called Dipoli, for the Helsinki University of Technology, for which the jury representative of the Finnish Association of Architects was Alvar Aalto. No first prize was awarded, but the entry by Raili and Reima Pietilä, titled 'Luolamiesten häämarssi' ('The cavemen's wedding march'), which had received joint second prize, was awarded the commission. When Dipoli was completed in 1966 - the same year as Kaleva Church - it sparked a heated debate.

The younger generation of architects in Finland, who were committed to a highly rationalist approach they referred to as constructivism, did not even want to try to

advocating the use of various modern materials, such as glass, and promoting a new notion of sculpture, of which the space created or delimited by the sculpture is an integral part of the artwork. 


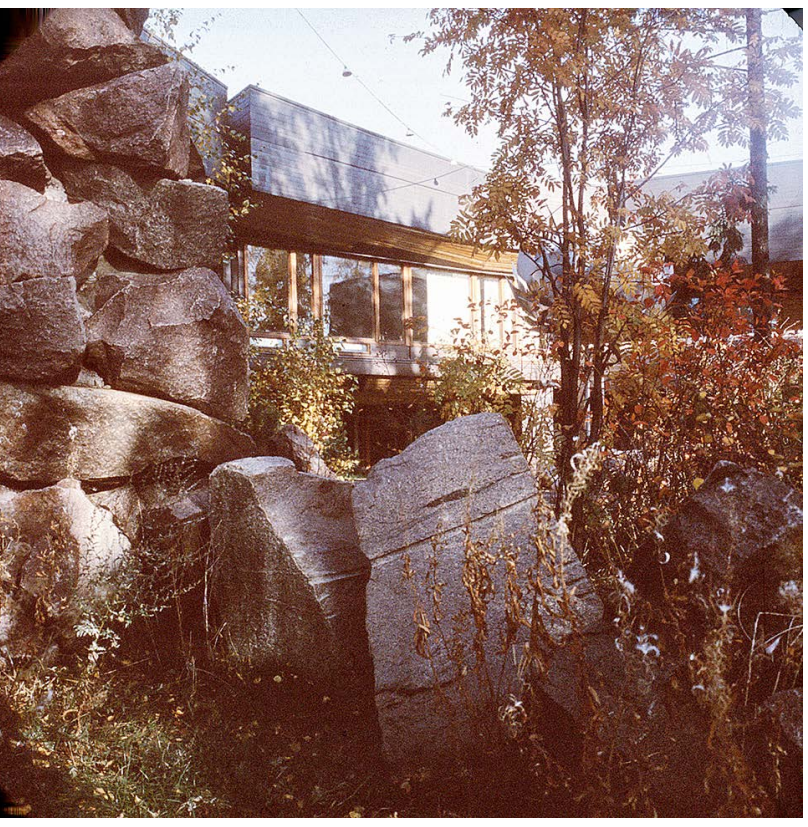

Dipoli (1961-7), exterior view (s.d.). Author's archives (Pietilä office donation).

remained allusive, and the time was not yet ripe for understanding a work whose form language did not rely on previously familiar semantics and vocabulary.

After the completion of Dipoli, there was a quiet period lasting several years during which Raili and Reima Pietilä did not receive any new building commissions, despite their successes in architectural competitions. One positive repercussion of this, however, was that in 1973 Reima Pietilä was offered a professorship in architecture at the University of Oulu in northern Finland, which he gladly accepted. This gave him the opportunity to develop more systematically his environmental-philosophical thinking, morphological theory of modern architecture, and new teaching methods. In his teaching, he emphasised in particular the importance of context and a sense of the whole, so that environmental, cultural, philosophical and social factors would converge in design, and thus influence the development of architecture. ${ }^{12}$ At the same time, he developed a theory of so-called 'cultural regionalism', which he also applied in his own design work. ${ }^{13}$

Although Pietilä enjoyed teaching and research, his years in Oulu became burdensome. Shortly after his appointment as a professor in 1973, his office received a large commission from the Kuwaiti government to design a complex of administrative buildings. Then, two years later, the Pietiläs were invited to design the central urban axis of a new district, Hervanta, in Tampere, the first stage of which was under construction while Pietilä was still teaching in Oulu. The Kuwait project in particular significantly increased the office's workload, and consequently, in 1979, Pietilä resigned from his position at the university.

Pietiläs time teaching in Oulu (19739) nevertheless had a significant influence on both his own architectural thinking and on the emergence of a northern regionalist trend, the so-called 'Oulu School'. Although Pietilä distanced himself from the postmodern regionalism of his students (see e.g. Pietilä 1982a: 6), the trend significantly

12 Pietilä had a very personal way of teaching, and also included a broad examination of international architectural trends and theories. See, e.g. Lehtimäki 2007: 81-95.

13 Cultural regionalism or 'cultural regionality' was Pietiläs own term, which to him meant an expression of genius loci and place identity based primarily on environmental memory (Pietilä 1982b). I have discussed the specific features of Pietiläs cultural regionalism elsewhere. See Broner 1985, 1986, 1987a, including my recent book, Broner 2019: 185-7, where I argue that Pietiläs architecture generally meets the criteria of Critical Regionalism, at least in relation to how it has been defined by Kenneth Frampton (1983: 21ff.). 
boosted the architectural debate in Finland in the 1980 ond also received international attention.

\section{Nature architecture}

It was not until the 1980 os that analytical tools suitable for interpreting Dipoli's nature-based free-form architecture first began to become available. This was partly due to a change of direction in the international theoretical debate, as represented by, among others, Christian Norberg-Schulz in his book Genius Loci: Towards a Phenomenology of Architecture (1980), in which he presented a phenomenological theory of place based on the philosophy of Martin Heidegger. Some of the key concepts in Pietiläs own theoretical work, such as 'memory of environment' and 'nature-architecture', have also contributed to a new understanding of the meaning of Dipoli's form language. Pietilä clearly considered the concept of genius loci to be the most important premise for his own work. He often referred to it during the 1980 s (e.g. Pietilä 1982b), but also coined new expressions in Finnish, which he perhaps considered better suited to his own work, for example, henkisen omalaatuisuuden tila, literally 'a state of spiritual originality' (Nurmela 1982).

Pietilä did not use the term 'nature architecture' consistently until around 1985, when the Museum of Finnish Architecture in Helsinki organised an exhibition of the works of Raili and Reima Pietilä titled Intermediate Zones in Modern Architecture. In an interview in the book accompanying the exhibition, Pietilä observed:

Nature-architecture is a concept of multiple ideas still unknown in our language. I myself use it now for the first time to signify the way in which

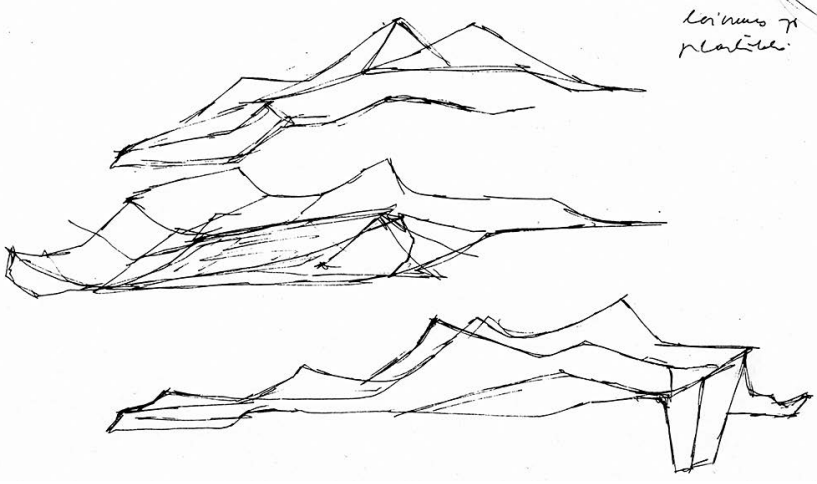

Sketches for Dipoli during the competition phase (1961). (c) Museum of Finnish Architecture.

nature and architecture interact as elements of a genius loci. The peaceful and even mutually beneficial coexistence of nature and architecture in a state of existence is the genius loci approach. (Norri 1985: 14-15)

Although the Kaleva Church already incorporated features that imitated nature, Dipoli was more clearly Pietiläs first concrete experiment in nature-architecture: a sculptural 'morphological study of the forest', a plastic work of earth art. Pietilä explained how when working on the competition entry he had zig-zagged across the site 'until his feet achieved an understanding of the tactile memory of the rock formation' (Pietilä 1982b). The building's organic form language, including its rough boulders, originated as a recollection of the site, while the interior represents an independent image of the wider landscape. The building also comprises another characteristic component of Pietilä's nature-architecture, namely a 'dual façade', where the outdoor space is projected onto one surface and the interior space onto another. As architectonic systems, they do not correspond to each other - just as the interior 


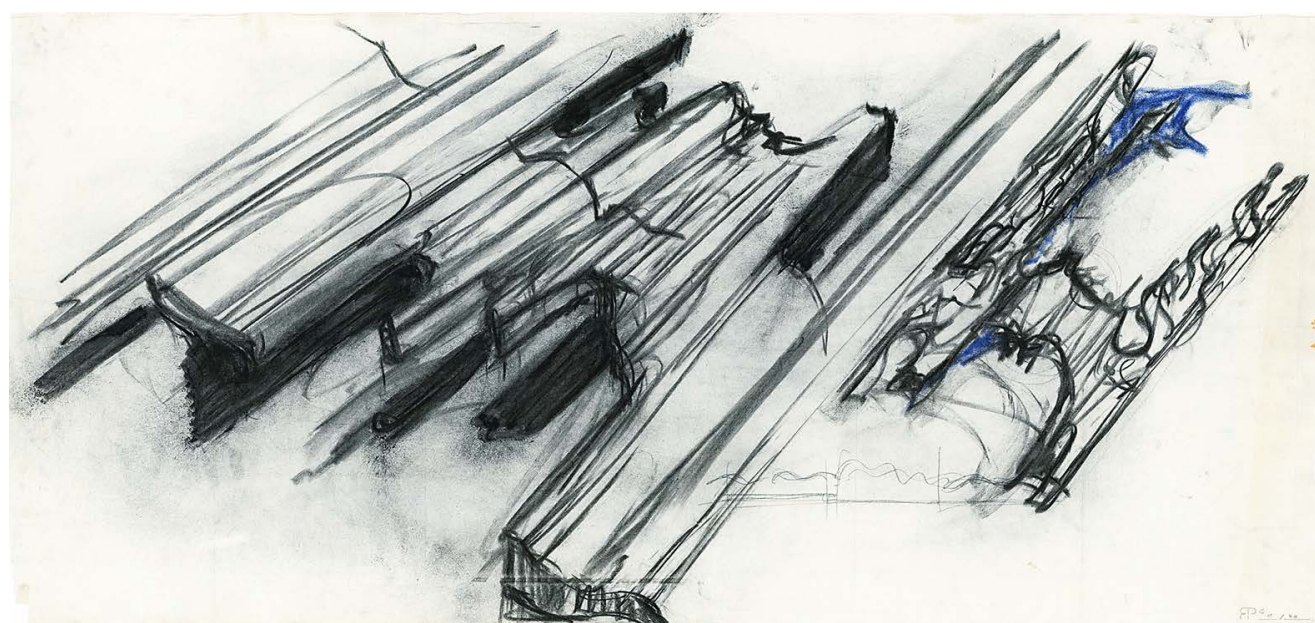

Finnish Embassy in New Delhi, sketch (s.d.). (c) Museum of Finnish Architecture.

of a cave is not a negative image of its surrounding strata. ${ }^{14}$

Perhaps the most impressive manifestation of the idea of nature-architecture is the Finnish Embassy in New Delhi (19805), India. The Pietiläs had won the architectural competition for the new embassy building already in 1963, but they did not receive the building commission until 1980, almost twenty years later. When the project was resumed, it could be seen that its architecture had not become outdated, with a need only for modifications to the room programme. When sketching ideas for the competition entry, Reima Pietilä had imagined views of an Arctic land, such as a wind-swept snowy landscape, and it was this metaphor he wanted to recreate as a 'nature image' of Finland in India (Quantrill 1985: 223). The snowy landscape is represented by the building's huge

14 After the Dipoli building (1961-6), Pietilä applied the Baroque idea of a 'dual facade' in some of his other buildings, too, for example in Mäntyniemi, the official residence of the President of Finland (1983-93), where his starting point had likewise been to build a metaphor for a rocky natural environment. undulating concrete roof, painted white. Although the overall composition of the building is fragmentary, the flat sculptural roof serves as a unifying factor between the different parts. In addition to its culturalsymbolic meaning, it also has the function of protecting the interior against India's scorching heat and monsoon rains (Broner 1987b: 68-83).

The main source of the form language for almost all the buildings designed by Raili and Reima Pietilä was in one way or another the natural environment - forests and landscapes, ancient rock formations, the clouds and sky, snow and ice, the topography of the terrain, and even animals. Pietiläs nature-architecture 'imitates' the morphological characteristics of the environment and the spirit of the place, the genius loci, as manifested through the use of metaphors. According to Aristotle's classical theory of mimesis, art is the imitation of nature. In his theory, however, nature is understood as the universal perfection of form, that is, nature refers to what is universal in human life. Classical theory, then, does not mean copying the external forms of nature or the physical environment, but the task of art is rather to strive towards the 


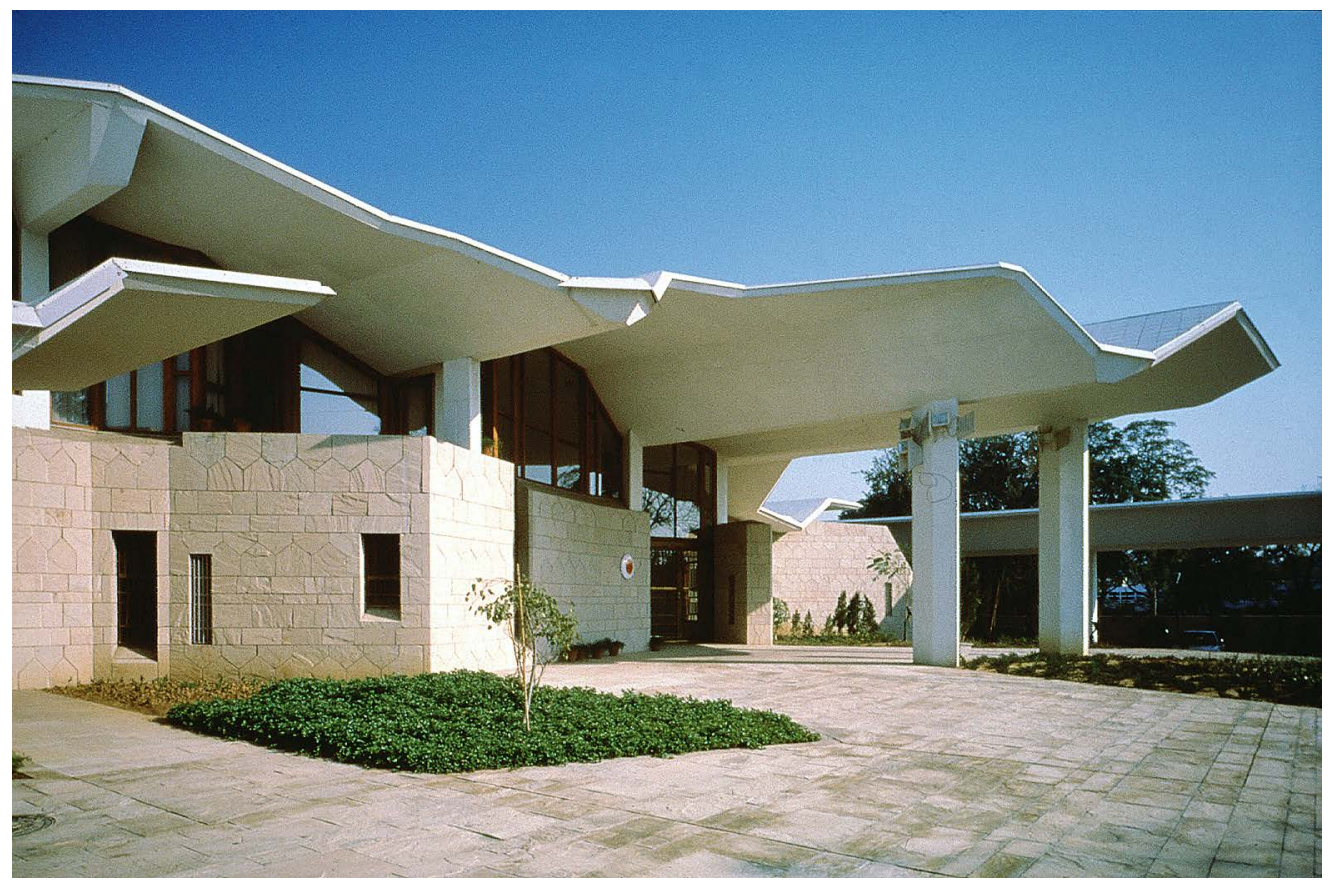

Finnish Embassy in New Delhi (1963, 1983-5), exterior view (s.d.). (c) Author's archives (Pietilä office donation).

ideal and to reveal the 'essential features of the original.'15 Compared to classical theory, Pietiläs starting points are clearly different. Nevertheless, the theoretical basis of Pietiläs nature-architecture can be interpreted as a kind of mimesis theory, because its basic idea is the 'imitation of nature'. Indeed, it is a romantic kind of mimesis in which the object of imitation is the local natural environment - not only its physical but also its metaphysical dimensions, which include both temporal depth and the cultural metaphors and meanings associated with nature.

\section{'Shamanism' as a design methodology}

A central part of Pietiläs life's work involved theoretical reflection on architecture. His aim was to create a theory that would lead

15 See Aristotle's Theory of Poetry and Fine Arts 1894/1951: 121-62: 'Imitation as an aesthetic term? to 'new architectures' and 'which will not reject alternatives but will actually produce them' (Pietilä 1968: 51). In an interview published in the Helsingin Sanomat newspaper in 1983 to commemorate his 6oth birthday, he stated that he had always remained faithful to his role in architectural theory: 'Every building is, in fact, an experiment in constructing this theory and not an end result in itself' (Maunula 1983).

Pietilä worked on theory throughout his career, not only in words but also in images. He had a particularly rich and multidimensional imagination - and here one might prefer to use a term from Kant's metaphysics, Einbildungskraft, that is, the 'power of imagination' (Kant 1781/1998). In Kant's philosophy, the power of imagination refers to the transcendental power of the imagination and the freedom to move between intuition and a structured understanding (Heidegger 1997: $\$ 11-20$ : e.g., 59, 68 et passim). It is just in this way, too, 
that Pietilä characterised his own way of working (Broner 2019: 32-3, 36-7, 46-7). 'Intermediate zone' (in Finnish, välimaasto) was one of Pietiläs favoured terms, though he preferably referred to it in the plural. The latter was also the title of the exhibition of Raili and Reima Pietiläs architecture held at the Museum of Finnish Architecture in 1985, as mentioned earlier, but above all the term described Pietiläs view of how he placed himself theoretically and philosophically on the world map of modern architecture, among its masters and other architects: he placed himself between them, in the intermediate space or zone of the 'no one's land' (Pietilä 1988: 93-100). He also coined new words in the Finnish language, so that issues and phenomena could be talked about more precisely, with the right kind of nuance. He presented these verbal and pictorial developments in theory in several exhibitions in Finland.

In his first-ever exhibition, titled 'Morphology and Urbanism' (1960), Pietilä emphasised the potential of the study of morphology in promoting the harmonisation of culture in urban planning, as well as calling for art as the basis for all architectural form. ${ }^{16}$ Issues of morphology were also the subject of Pietiläs second exhibition, entitled 'Zone' (Vyöhyke, 1967), in which he examined in particular the 'border zone', that is, the zone that arises when 'two fields' meet, thus mediating the transition from theory to visual realisation and the emergence of architecture (Pietilä 1968: 51-4). The themes of Pietiläs third exhibition 'Space Garden' (Tilatarha, 1971) were space, theory, the environment and the connections between them. In it he

16 Morfologia Urbanismi Reima Pietilä. Pinx 3.9.-15.9.196o. Galleria Pinx, Helsinki. Exhibition pamphlet. reflected on the nature of the visual subjects and ingredients that emerge in architecture and examined how best to display them. The exhibition also featured a visualverbal analysis of northern environmental types, using concepts such as spatial morphology, landscape topology, and environmental typology (Pietilä 1971: 1).

Morphology, topology, and typology became topical theoretical issues with the search for a new direction in architecture through the concept of regionality, as international modernism was in crisis. Pietilä was at that time the only architect in Finland addressing these themes. In the 'Space Garden' exhibition, he defined architecture as 'research on spatial reality' (Pietilä 1971:2) and argued that architecture would improve if we were more aware of the psychological meanings of architecture and the environment' (ibid. p. 4). Pietilä referred to the need for anthropological, culturalgeographical, and cultural-ecological research in order to avoid the environmental damage caused by the 'unbridled spread of only a few genres of architecture' (ibid. p. 6). In a way, the exhibition also served as an introduction to the phenomenology of architecture - years before phenomenology became a favourite topic of discussion among architects in Finland.

The exhibitions of the 1960 s and 1970 s demonstrated Pietiläs profound interest in the study of morphology, which became a common thread through his later architecture. 'Only a fraction of modernist buildings has a character and originality provided by a strong form language', he stated when I interviewed him in 1987, adding: 'I presume this theme forms the subject of my research' (Broner 2019: 74-5). Pietilä also worked quite systematically within his chosen area: 'For the past thirty years I have persistently been considering the "gap in modernism" - not that which is typical 
or most frequently encountered, but rather that which is yet undiscovered, that which is only just forming or emerging', to which he then added: 'The phenomena of futurism are my field, not the prevalent majorities, nor the qualitative typicalities of the modernism we know' (ibid. pp. 92-5).

Pietilä had sometimes referred to his working method as 'culturally oriented holistic design' (Norri 1985: 20-1). This entailed a complex intuitive process based on creative imagination and aimed at the 'problematisation of architecture'. The conceptual dimension was always part of Pietiläs work, though it was not a rational system, but rather - as he described the design process - 'something is born as if out of play, like out of a void, and then, little by little, this baby has to be taught to talk in order to become a grown-up' (Broner 2019: 76-7). The idea of 'teaching a baby to talk' meant developing a project's initial ideas through various stages in order to reach a completed design, as well as working on it so that it becomes an integral part of its own cultural context.

Pietiläs exhibitions further demonstrated the paths in the mind of the architect along which he proceeded during the draft phase of a design task. They also showed his working method, which was characterised by the simultaneous and intuitive use of texts and images. Three overlapping events can be distinguished in his design approach - referred to by Pietilä as shamanism, verbal sketching and image sketching - which together form a multifaceted creative process. These events refer to the various, often simultaneous and intuitive thought processes that the architect experimented with in the early stages of a design, and from which he extracted ideas he then wished to continue: 'I create various scenarios in my mind, and as a result I can draw a parametric form from these ingredients' (Broner 2019: 46-7).

One of Pietilä's key concepts is 'ingredient' (in Finnish, aines, also meaning element or substance). According to him, man has the ability to generate the ingredients from which architecture can be created: 'an ingredient is like an intermediate zone between really existing and really imaginable things' (Broner 2019: 46-7). It resembles the border zone as depicted in the 'Zone' exhibition, at the conjunction of two fields, for example, when moving from the world of mental imagery to concrete pictorial expression.

What, then, is 'shamanism' in architecture? For Pietilä, it was the creative imagination, the natural movement of the imagination in time and space, on both this side and beyond the border of consciousness, a quest for knowledge, while preferably remaining within the border zones. So, what kind of architect is a shaman? According to Pietilä:
A shaman is a realiser-artist, someone who trusts his intuition, because it is functioning and in good shape. Just as an artist moulding his artwork trusts in his ability to express elements of both content and form in the order in which they happen and agree to be expressed. An artist has to be satisfied with the artwork's own way of coming into existence, as well as with the imperfection whereby the influence of his artistic means finally meets its limits. (Broner 2019: 24-5)

A shamanistic creative imagination, and the clairvoyant visualisation associated with it, provided Pietilä with a basis for envisioning architecture: 
Since I can see in general, it is easy for me to draw. When you pose a question, I first see it as a kind of vision. A visual field is formed, of which I can make a diagram, and then I start to work it out verbally. Usually, I can see several different models which come to mind simultaneously, and I manage to capture something on paper. Later on, when I perhaps return to the matter, some other model can still suddenly come to mind. (Broner 2019: 94-5)

Pietilä spoke even more about his relationship with shamanism. In the interview I made with him in 1987, he described how as a teenager he had attended lectures at the University of Turku by Professor Paavo Ravila on UralAltaic philology, and how the professor had made the audience 'fall into a trance' and 'experience the intimate feeling of the trances and the intellectual awake-dreams of transcendence'. As a brilliant orator, Ravila was for the young Pietilä his 'first model' of a shaman. A second model, as he put it, was related, via the artist Akseli Gallen-Kallela, to esoteric interpretations of the Finnish national epic The Kalevala and its nature-related mysticism. A third model was the interpretation of the shaman as a seeker of knowledge or 'traveller' into the deeper states of consciousness, reaching beyond temporal strata (Broner 2019: 20-3).

Pietilä described, for example, how through his imagination he could search for information about the life in the ancient Finnish village of Pieksämäki 10,000 years ago:

I picture in my mind the village of Talvikylä, which has now been excavated. It burned down long ago; the charcoal still exists below ground, even though everything else has vanished. Such a place in Pre-Kalevala Finland - what did it look like, what were the views like? In one's imagination one can freely move about there, one can live the life of this ancient village in Pieksämäki. The buildings of the village are known fairly accurately; they were vertical timber structures. Their elevations were quite similar to those of a native American village. Large tree trunks forming squares, the treetops bent, the upper part straight, with smoke coming out... Tipi-like huts, giant conical huts. (Broner 2019: 26-7)

The intuitive experience of the different strata of time and place also inspired Pietilä to compare shamanistic and scientific approaches. He had read about archaeological excavations in Talvikylä and, inspired by what he had read, was able to empathise with life in the village during the prehistoric era, but he also wanted to be able explain it using objective terminology.

This is that kind of time-shifting event. You can perform it in a contemporary way, for example, by making use of scientific premises. [Or] one can make a so-called shamanistic excursion to such a conical hut village and follow the course of the day ... This kind of operation, of turning back time 10,000 years, is for me perhaps entirely possible. Are we then talking about archaeology, shamanism, or time shifting? In any case, it is possible to reconstruct that temporal event on the basis of existing remains and achieve a similar-looking result, a vision, like a magician or visionary going back in time. (Broner 2019: 26-9) 
Pietilä was preoccupied, however, with the character of shamanistic time consciousness, the mystery of which he continued to reflect upon:

But then again, I am bothered by the question of shamanistic time consciousness. Does it presume everything is happening at the same time? When you connect in the blink of an eye to something far beyond, does it exist in the same time as we do, or does it exist in a kind of psychological timelessness? (Broner 2019: 28-9)

Furthermore, the experience of these different layers of time became one of the essential starting points by which Pietilä was able to envision architecture. Two or three temporal dimensions were particularly important to him: firstly, the archaeological past and the images it evoked and secondly, in contrast, the cultural spirit of the present, but also, thirdly, a forward-looking futurism. Temporal mobility also meant for Pietilä a connection to the Finno-Ugric 'linguistic-etymological continuum', from which he sought an archetypal basis for his work (Broner 2019: 30-3, 82-3).

Alongside shamanism, intuitive 'verbal sketching and image sketching' were integral to Pietiläs hunt for ideas in his early architectural sketching phases. He explained, for instance, about how the early stages of the design for Dipoli possessed a 'dreamlike atmosphere', which felt like 'clairvoyance, the welling up of surreal abstractions' (Norri 1985: 26-7). He also compared his way of working to the 'automatic writing' practised by the Surrealists in the early twentieth century - the spontaneous sketching of ideas in words and images, in which one searches for a character 'moving with the assurance of a sleepwalker in an open field' (ibid. pp. 26, 30).
Pietiläs 'verbal sketching' also entailed a spontaneous way of producing metaphors, which he then converted into a 'verbalised language'. The ideas stage thus included a slightly more rational component: 'I make series and systematise. [With these tricks] ... one can see at a glance the task at hand, like the table of contents in a book' (Broner 2019: 40-1). The idea of forming series was central to Pietilä. He spoke of 'troika pluralism, meaning that there should be at least three different potential series in the conception of architecture - but not much more than that, as Pietilä felt that the pluralism of architecture should be limited, that is, kept within reasonable limits (ibid. pp. 72-5).

As mentioned earlier, almost all of the Pietiläs' most important building commissions came through winning architectural competitions. During the preliminary stage of their competition proposals, Raili and Reima Pietilä often left home to go 'somewhere else': a country cottage holiday, a train journey or even a trip abroad, away from their everyday setting, so that other matters would not disturb their concentration. Many of the competition entries were made during summer holidays, while observing the natural environment and sketching the initial images for their proposals. For instance, the character of the Finnish Embassy in New Delhi was conceived amidst the scenic landscape of Lake Päijänne in Korpilahti (Pietilä 1982b), the idea for Metso, the Tampere City Library, began to develop in the Aran Islands in Ireland (ibid.), and the first visions for Mäntyniemi, the official residence of the President of Finland, emerged in Hankasalmi, while 'rowing for days on end in the waters where [the provinces of] Häme and Savo meet' (Maunula 1984: 11).

The Metso Library $(1978-86)$ is an illustrative example of Raili and Reima 


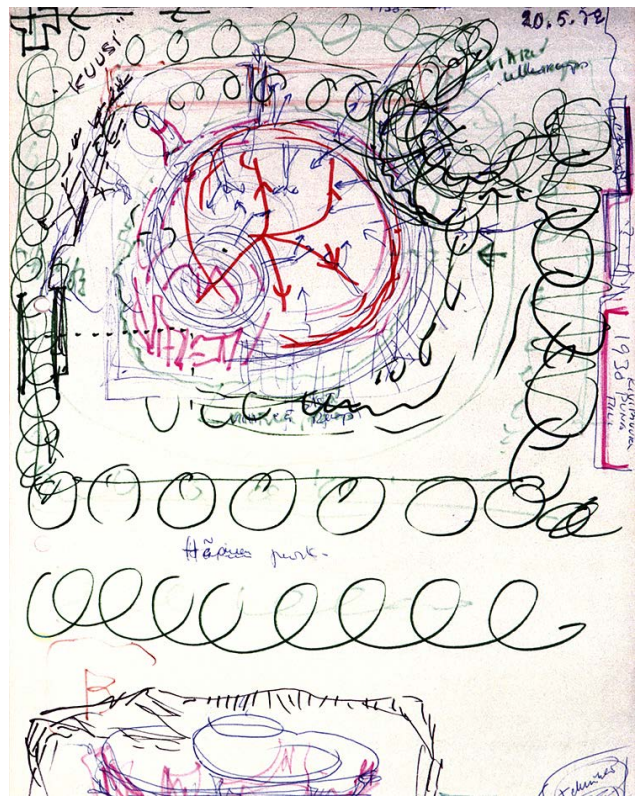

Above: Sketches for Metso during the competition phase (1978). Below: Metso Library (1978-85), exterior view (s.d.). Author's archives (Pietilä office donation).
Pietiläs way of sketching the first ideas for their architecture. In the summer of 1978 , the Pietiläs travelled to Ireland to contemplate their competition proposal. The historical stone walls they saw there, as well as the spiral forms of Celtic brooches, led them to the initial ideas for the architectural design of Metso. Later, the figure of a bird, capercaillie (in Finnish, metso), which lives in the wilderness forests of Finland, began to emerge - as well as providing the name of their competition entry 'Soidinkuvat' ('Mating dance pictures'). Pietilä explained, however, that before the architectural form of the library building had crystallised, he imagined himself on the construction site, moving in the depths of his mind back to the Ice Age 8,000-10,000 years ago, when the ice sheet over Finland began to melt, gradually reaching its current form. These images created by the forces of nature,
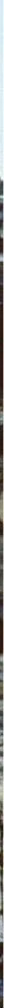
together with the figure of the capercaillie, ultimately served as the ingredients for the 'localised shape' of Metso's architecture (Broner 1988: 84-6).

'Whenever and in whatever form the mental impulses choose to come, they must be taken as they are, and one must be patient, to wait and see what becomes of them in the future', Pietilä once observed, and continued: 'The seizing of an idea is a process which one doesn't seem to be able to influence consciously' (Norri 1985: 26-7).

\section{The onion bulb model of reality}

I have described above something of Reima Pietiläs architecture and way of working. There was a strong esoteric dimension to his thinking, which he possibly embraced as a legacy of his early home life (Quantrill 1985: 27). An interest in the esoteric, including Theosophy and Anthroposophy, had been quite common in the early twentieth century among expressionist architects in the German-speaking countries, as well as among the English Arts and Crafts movement (Colquhoun 2002: 257, fn. 9). Similarly, artists from that era associated with abstract art, Futurism and Surrealism adopted influences from esoteric thinking (Kokkinen et al. 2020: 2212). Correspondingly, there was considerable interest in the early twentieth century among the Finnish intelligentsia, writers, composers, artists and architects in esoteric movements, especially in Theosophy, Freemasonry and Anthroposophy (ibid. pp. $223 \mathrm{ff}$.).

Reima Pietilä had stated that he was inspired by the early twentieth-century German expressionists and Italian Futurists as well as the Surrealists (Broner 2019: 92-5, 100-1, 110-11). Sometimes, he even experimented with 'automatic writing', as made famous by the Surrealists, when sketching his architectural ideas (Norri 1985: 26-7). But shamanism in particular was an important source of spirituality for him, for which he referred to Paavo Ravila and Akseli Gallen-Kallela as role models

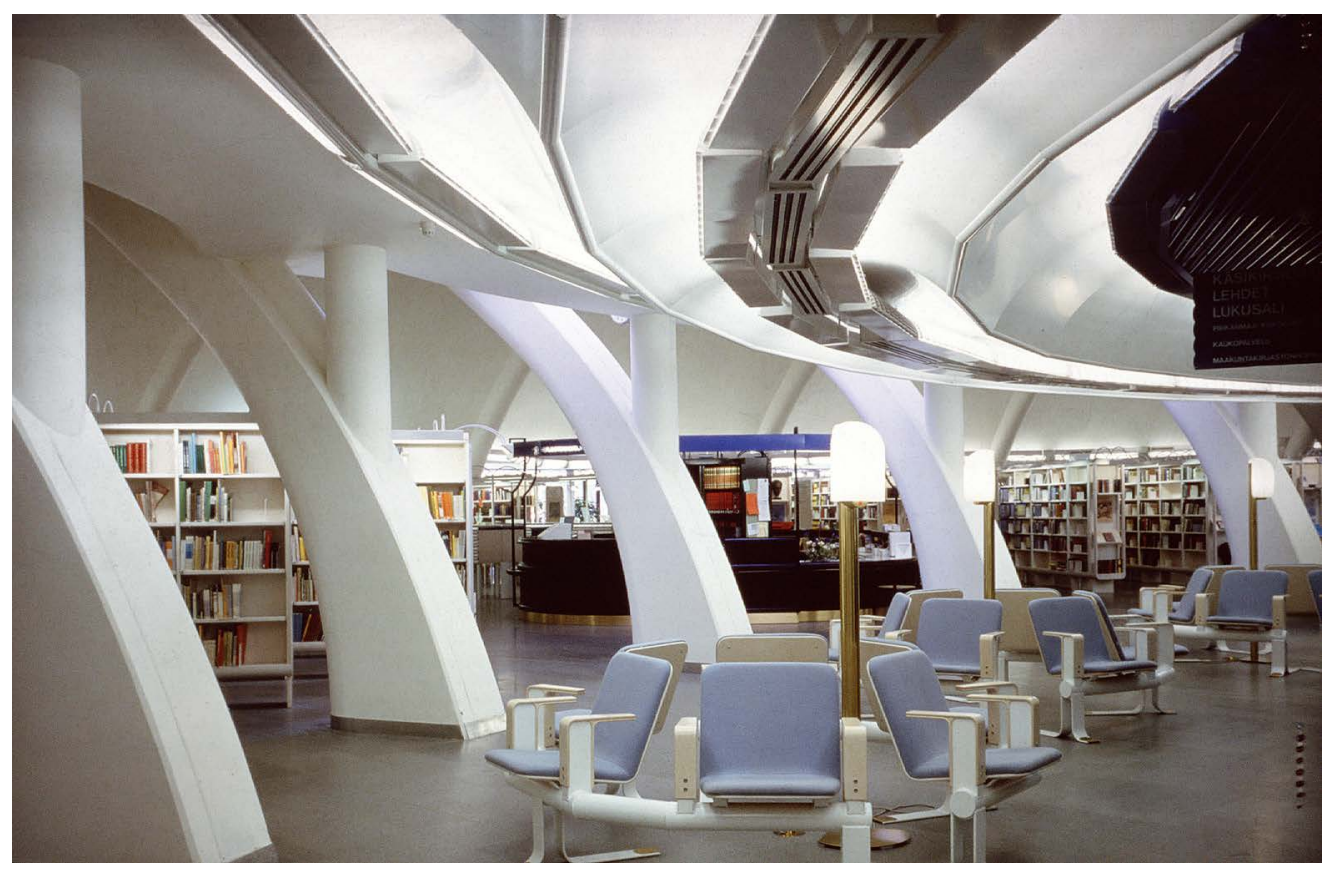

Metso Library (1978-85), interior view (s.d.). Author's archives (Pietilä office donation). 


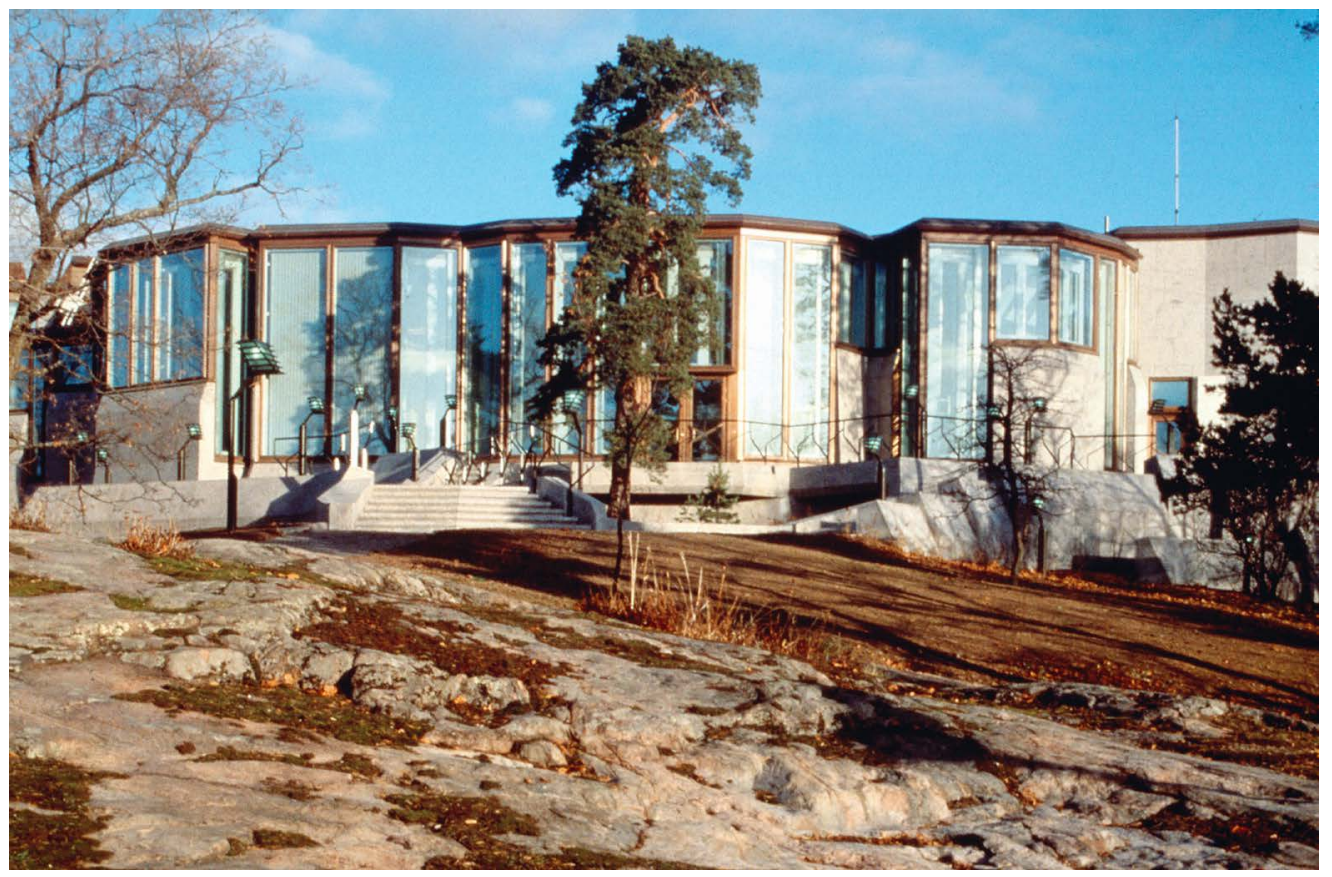

Mäntyniemi (1983-93), exterior view (s.d.). (c) Museum of Finnish Architecture.

(Broner 2019: 20-5). There are even interesting similarities in the way Pietilä and Gallen-Kallela created their art. For both, Finnish nature and nature-mysticism formed an obvious basis for their clairvoyant creativity, and both utilised symbols in their art. In his artwork, GallenKallela used, for instance, similar symbols as the Theosophical movement, the pictorial symbolism of esoteric movements and a mystical interpretation of The Kalevala (Kokkinen 2019: 90-108 et passim). Pietilä's work, on the other hand, primarily reflects metaphors of natural phenomena, yet he also symbolically utilised many other sources of inspiration, such as animal figures or different meanings of light (Broner 2019: 136-57, 176-7, 184-209). In the 1983 Helsingin Sanomat interview, Pietilä also spoke about his affinity for Native American cultures, their earth sculptures, shamanism and animism (Maunula 1983).

Reima Pietiläs active years coincided with the last decades of the twentieth century, when Western society was dominated by a materialistic worldview. Materialism also influenced the prevailing paradigms in the arts and sciences, which contributed to curbing public opinion about esoterically oriented artists and thinkers. Nevertheless, Pietilä never disguised his metaphysical conception of reality, but rather spoke openly about his own premises, for example in relation to shamanism. He also described shamanistic clairvoyance as a completely natural, intuitive ability, as well as its utilisation in the architectural design process (Broner 2019: 20-33). It is worth distinguishing, however, between Pietiläs personal, intuitive or imaginary 'shamanism' and the Finnish shamanist tradition studied in ethnography, which includes its own established practices (cf. Siikala 1992: 16-22).

Due to its metaphysical meaning, Pietiläss architecture cannot be explained in 
its entirety. During the 1987 interview, in attempting to clarify the relationship of our human existence to reality, Pietilä took to pencil and paper: 'Now I will sketch here this onion bulb-like diagram of reality, the onion bulb model of reality. I have several models, this onion model is one of those that I often use. Man creates layers of the bulb but cannot penetrate to its core, the dark core of reality. And neither can he float freely outside, beyond his own limits' (Broner 2019: 94-5). According to him, architecture, just like human life generally, has a dimension that remains secret to us, one that we can never ultimately explain. He later added the thought: 'Perhaps a building is a good set of means for depicting a reality that we could not adequately disclose in some other form' (Pietilä 1987).

Plato's allegory of the cave provides a key to understanding Pietilä's architectural approach and the related visual and verbal thought processes - creative imagination, visual sketching and verbal sketching - and he himself referred to the allegory in various contexts. For Pietilä, theoretical concepts were, in fact, merely tools or 'approximations of architecture'. If we really want to understand what is real - be it an object or an idea - according to him, we must first have an image, that is, a kind of conception of what that object or idea is. In addition to observing such a mirror image of the insight, that is, the idea of the reality that we are trying to grasp, we must also glimpse the other side of that mirror image - in other words, we should leave the cave described by Plato and see the sun-lit reality, at least for a moment - in order to be able to sufficiently conceptualise that insight and to create an expression for it, that is, to give it form.

It is obvious that in Pietilä's metaphor, it is precisely that 'other side' of the mirror image - a clairvoyant insight - that provides the internal connection pointing the way to the solution for an architectural form. He himself, however, would refer to the objectification of the problem related to the creation of form, rather than its solution. He felt that his task as an architect was to raise questions, rather than rushing to answer them. Here again, one can see a philosophical connection with Wittgenstein, who also emphasised the importance of asking questions in order to make an answer possible at all. In fact, Pietiläs entire way of working as an architect was based on the view that architecture itself has a generative ability to produce answers - that is, 'architecture responds in the way the question is posed'.

\section{English translation by Gareth Griffiths.}

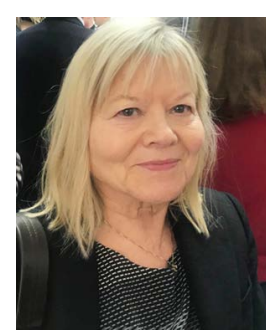

Kaisa Broner (BronerBauer) is a Finnish architect, Doctor of Science (Tech./Arch., Helsinki University of Technology, presently Aalto University), and Professor Emerita of Architecture (19862010) at the University of Oulu, Finland. She holds also a doctorate in urban studies from École des hautes études en sciences sociales (EHESS), Paris, and a master's degree in historic preservation from Columbia University, New York. She has worked for periods as an architect and researcher in Finland, France and the United States and as a visiting professor in Japan (University of Tokyo, 1995-7) and Estonia (Estonian Academy of Arts, 2008). She is the author of numerous publications on architecture and historic preservation in Finland and abroad, including New York face à son patrimoine. Le secteur historique de SoHo (Pierre Margada, 1986) and her most recent book Visions of Architecture: Reima Pietilä and the Meanings of Form / Arkkitehtuurin visiot. Reima Pietilä ja muodon merkitykset (OKU Publishing, 2019). Her present research focuses on philosophical themes in architecture and urban space. 


\section{References}

Aalto, Alvar. 1958. 'Artikkelin asemasta', Arkkitehti, 1-2: 27.

Aristotle's Theory of Poetry and Fine Arts [first published in 1894], translated and with critical comments by S. H. Butcher (New York: Dover Publications, 1951).

Blom, Kati. 2007. 'Mica Moraine and emotions', in Hikes into Pietilä Terrain, eds. Aino Niskanen, Sirkkaliisa Jetsonen and Tommi Lindh, Taiteentutkija, 4 (Helsinki: Rakennustaiteen seura / Taidehistorian seura), 23-34.

Broner, Kaisa. 1985. 'The architecture of Raili and Reima Pietilä: a strategy of resistance, in Form. Function. Finland, 2: 20-7.

- - 1986. 'The work of Raili and Reima Pietilä and regionalism in Finland', Architecture and Collective Memory: Seminar on Architecture and Urban Planning in Finland 1986 (Helsinki: SAFA, Finnish Association of Architects), 25-34.

- - 1987a. 'The architecture of Raili and Reima Pietilä or regionalism re-defined', Le Carré Bleu, 3-4: 74-8.

- - 1987b. 'The Finnish Embassy in New Delhi', Living Architecture, 6: 68-83.

- - 1988. 'Tampere Main Library: the number of archetypes and symbolic images', $A+U$ Architecture and Urbanism, 1: 84-6.

- -2019. Visions of Architecture: Reima Pietilä and the Meanings of Form / Arkkitehtuurin Visiot-Reima Pietilä ja muodon merkitykset, trans. Gareth Griffiths, Jyri Kokkonen and Kimmo Korhonen (Helsinki: Oku Publishing).

Colquhoun, Alan. 2002. Modern Architecture (Oxford and New York: Oxford University Press).

Connah, Roger, and Reima Pietilä. 1982. 'Unsettled architecture / Architettura irrequita, Spazio e Societa / Space and Society: International Journal of Architecture and Environmental Design, 17: 6-25.

Frampton, Kenneth. 1983. 'Towards a critical regionalism: six points for an architecture of resistance, in The Anti-Aesthetic: Essays of Postmodern Culture, ed. Hal Foster (Townsend, WA: Bay Press), 16-30.

Heidegger, Martin. 1997. Kant and The Problem of Metaphysics [orig. Kant und das Problem der Metaphysik, 1973], transl. Richard Taft
(Bloomington and Indianapolis: Indiana University Press).

Kant, Immanuel. 1998. Critique of Pure Reason [orig. Kritik der reinen Vernunft, 1781], trans. Paul Guyer and Allen W. Wood (Cambridge University Press).

Kokkinen, Nina. 2019. Totuuden etsijät. Esoteerinen henkisyys Akseli Gallen-Kallelan, Pekka Halosen ja Hugo Simbergin taiteessa (Tampere: Vastapaino).

Kokkinen, Nina, Tiina Mahlamäki, and Maarit Leskelä-Kärki. 2020. 'Esoteerisuus taiteessa ja kirjallisuudessa', in Moderni esoteerisuus ja okkultismi Suomessa, eds. Tiina Mahlamäki and Nina Kokkinen (Tampere: Vastapaino), 221-45.

Lehtimäki, Marianne. 2007. 'Conversational training in environmental knowledge', in Hikes into Pietilä Terrain, eds. Aino Niskanen, Sirkkaliisa Jetsonen and Tommi Lindh, Taiteentutkija 4 (Helsinki: Rakennustaiteen seura / Taidehistorian seura), 81-95.

Maunula, Leena. 1983. 'Arkkitehdin asia on löytää paikan henki', Helsingin Sanomat, 25.8.1983.

—-1984. 'Maan ja jään arkkitehtuuria', Helsingin Sanomat, 17.5.1984.

Niskanen, Aino. 2008. 'Pietilä Team 10:n piirissä, in Raili ja Reima Pietilä, modernin arkkitehtuurin haastajat, eds. Eriika Johansson, Kristiina Paatero and Timo Tuomi (Helsinki: Suomen rakennustaiteen museo), 24-31.

Norberg-Schulz, Christian. 1980. Genius Loci: Towards a Phenomenology of Architecture (London: Academy Editions).

Norri, Marja-Riitta. 1985. 'Arkkitehtuuri ja kulttuurin paikallisuus. Reima Pietilän haastattelu' / Architecture and cultural regionality', in Pietilä. Modernin arkkitehtuurin välimaastoissa / Intermediate Zones in Architecture, eds. Marja-Riitta Norri et al. (Helsinki: Suomen rakennustaiteen museo \& Jyväskylä: Alvar Aalto Museo), 6-32.

Nurmela, Kari A., 1982. 'Arkkitehtiemme uusi moraali on opittava', Reima Pietilä newspaper interview [name of the newspaper missing], given by the Pietiläs to the author in autumn 1982.

Passinmäki, Pekka. 2003. 'Reima Pietilä ja suunnittelukokeilut', Niin \& Näin, 3: 84-5. 
Pietilä, Reima, 1958. 'Thème : la morphologie de l'expression plastique', Le Carré Bleu, 1: $1-5$.

-—1968. 'Vyöhyke - The Zone', Arkkitehti, 1: $49-56$.

- -1971. 'Tilatarha', Exhibition brochure, 21.4.-12.6.1971 (Helsinki: Suomen rakennustaiteen museo).

- - 1973. 'Arkkitehtuuri ja teknokulttuurin maailma', inaugural lecture, 5.12.1973, University of Oulu, Kaltio, 1: 19-21.

- - 1974. 'An introspective interview', $A+U$ Architecture and Urbanism, 9: 96-9.

-1982a. 'Avoin kirje Pekka Suhoselle', Arkkitehtiuutiset, 9: 5-7.

- - 1982b. 'Genius loci: personal interpretations', in Genius Loci: A Search for Local Identity. Seminar on Architecture and Urban Planning in Finland 1982 (Helsinki: SAFA, Finnish Association of Architects).

- -1985a. 'Alkavat taas kysyä, mitä arkkitehtuuri oikein on?', Arkkitehtiuutiset, 15: $16-18$.

- - 1985b. 'Arkkitehtoninen lähestymistapa' I 'Architect's Approach to Architecture', in Pietilä. Modernin arkkitehtuurin välimaastoissa / Intermediate Zones in Architecture, eds. Marja-Riitta Norri et al. (Helsinki: Suomen rakennustaiteen museo; Jyväskylä: Alvar Aalto Museo), 113-20.

- -1987. Letter to Kaisa Broner, dated 21.2.1987, author's private archives.

- -1988. 'Intermediate zones in modern architecture: comments on the exhibition', in Modernity and Popular Culture, ed. Kaisa Broner (Jyväskylä: Alvar Aalto Museum; Helsinki: Museum of Finnish Architecture; Helsinki: Building Book Ltd), 93-100.

- - s.d. 'Nature: a cultural paradigm for architecture, unpublished article manuscript sent to the author by the Pietilä office, 8.12.1993.

Pietilä, Reima, and Raili Paatelainen. 1967. 'Dipoli: sanatarkasti muoto-oppia', Arkkitehti, 9: 14-20.

Quantrill, Malcolm. 1985. Architecture: Context and Modernism (Helsinki: Otava).

- -2007. 'Reima Pietilä: an alien in his native land', in Hikes into Pietilä Terrain, eds. Aino Niskanen, Sirkkaliisa Jetsonen and Tommi Lindh, Taiteentutkija, 4 (Helsinki: Rakennustaiteen seura / Taidehistorian seura), 125-38.
'Reima Pietilän haastattelu' [Interview with ReimaPietilä]. 1979. Yhteiskuntasuunnittelu, 1: $14-17$.

Schildt, Göran (ed.). 1972. Alvar Aalto. Luonnoksia (Helsinki: Otava).

Siikala, Anna-Leena. 1992. Suomalainen šamanismi (Helsinki: SKS). 